\title{
Helicobacter pylori Regulates the Apoptosis of Human Megakaryocyte Cells via NF-kB/IL-I7 Signaling
}

This article was published in the following Dove Press journal: OncoTargets and Therapy

\author{
Huyi Lei ${ }^{1,2}$ \\ Yongyong $\mathrm{Ma}^{\prime}$ \\ Jie Tan' \\ Qifa Liu' \\ 'Department of Hematology, Nanfang \\ Hospital, Southern Medical University, \\ Guangzhou, 510515, People's Republic of \\ China; ${ }^{2}$ Department of Hematology, The \\ Affiliated Hospital of Shao Xing \\ University (Shao Xing Municipal \\ Hospital), Shaoxing, 3|2000, Zhejiang, \\ People's Republic of China
}

Objective: To investigate the role of Helicobacter pylori (HP) on the regulation of NF- $\mathrm{kB}$ / IL-17 signaling, mechanisms underlying apoptosis in human megakaryocyte cell lines Dami. Methods: Firstly, the mouse model of immune thrombocytopenia (ITP) was established. Then, the mice were subjected to gastric perfusion with HP. Next, the changes in platelet and bone marrow megakaryocyte classification were assessed in each group. Human megakaryocyte Dami cells were treated with HP in vitro for 3, 6, or $9 \mathrm{~h}$; and the rates of apoptosis in each group were then evaluated with flow cytometry. Fluorescent quantitative PCR and Western blotting were implemented for assessing the expression of $\mathrm{Bcl}-2$ and $\mathrm{Bax}$, which are related to apoptosis, and $\mathrm{p} 65$, which is associated with the NF- $\mathrm{B}$ p pathway. The expression of these proteins was also evaluated after treatment with PDTC, an inhibitor of the NF- $\mathrm{BB}$ pathway inhibitor.

Results: In vivo, exogenous administration of HP was found to increase the optical density value for the anti-HP antibody in HP-infected BALB/c mice. Meanwhile, the platelet counts in the HP-infected ITP mice model were significantly reduced compared with non-infected ITP mice. In vitro, the apoptotic rate of Dami cells increased gradually with the prolongation of the exposure to HP; the most noticeable change was at $6 \mathrm{~h}$, and there was a significant difference between $0 \mathrm{~h}$ and $6 \mathrm{~h}$. The expression of Bax, p-p65, and IL-17 also increased progressively with the prolongation HP exposure, while the expression of anti-apoptotic Bcl2 protein decreased gradually, especially at $6 \mathrm{~h}$, and the expression of total p65 did not change significantly compared with baseline. Anecdotally, these effects were reversed by the application of pyrrolidine dithiocarbamate (PDTC), an inhibitor of NF- $\kappa$ B signaling.

Conclusion: HP can promote platelet destruction in ITP mice, and the underlying mechanisms may be related to accelerating apoptosis of megakaryocytes by the activation of the NF$\kappa \mathrm{B} / \mathrm{IL}-17$ pathway.

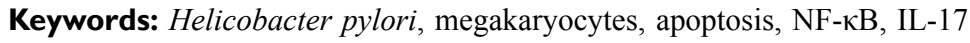

\section{Introduction}

Immune thrombocytopenia (ITP) is a frequent hemorrhagic disease that involves abnormal humoral and cellular immune function with massive platelet destruction, resulting in a significant reduction of circulating platelets. ITP may be acute or chronic, and the main clinical manifestations include spontaneous ecchymosis and stasis on the skin and mucous membranes, most commonly in the oral cavity, gingiva, and the nasal cavity, as well as subcutaneous bleeding in the extremities and menorrhagia, among others. ${ }^{1,2}$ Severe cases may be associated with intracranial
Correspondence: Qifa Liu Department of Hematology, Nanfang Hospital, Southern Medical University, 1838 North Guangzhou Road,

Guangzhou, 510515, People's Republic of China

Email liuqifa628@I63.com 
and visceral bleeding and may pose a severe lifethreatening risk. At present, the pathogenesis of ITP remains unclear and requires further investigation.

Helicobacter pylori (HP) is a gram-negative bacillus with parasitic activity in the gastric mucosa, which was first discovered in $1983 .{ }^{3}$ Clinically, HP infection is often associated with gastritis, peptic ulcers, and other related conditions. Amounting research has found it is also associated with other non-digestive diseases, such as autoimmune disorders, lymphoma, and iron deficiency anemia, among others. Autoimmune disorders encompass diseases caused by autoimmune responses to autoantigens, which may be caused by many factors. In recent years, an epidemiological investigation has shown infection by some pathogenic microorganisms can increase the incidence of some autoimmune diseases through multiple mechanisms. ${ }^{4}$ HP appears to influence the host immune response through a variety of factors and may be related to the pathogenesis of many autoimmune diseases. ${ }^{5-7}$ In particular, in 1998, scientists first observed eradication of HP was associated with a significant increase of platelet count and disappearance of anti-platelet autoantibodies, suggesting HP infection may be related to the pathogenesis of ITP. ${ }^{8}$ Subsequently, several studies have reported mean platelet counts to increase significantly after HP eradication in patients with ITP, without recurrence. ${ }^{9-12}$ Although the exact role of HP in the pathogenesis of ITP remains unclear, this has attracted increasing scientific attention, providing novel therapeutic targets for ITP in the future. ${ }^{13}$

The NF-kB pathway is currently known to modulate several physiological functions, such as the immune response, the inflammatory response, embryogenesis, thymus development, oxidative damage repair, tissue and organ aging, cell proliferation, and apoptosis, as well as other pathophysiological processes. ${ }^{14}$ Because the activation of NF-кB does not involve regulation of newly translated proteins, it represents a quick reaction upon cell injury, regulating the expression of various proteins to maintain vital cellular activities. Apoptosis-programmed cell death regulated by genes-has been observed to be important in ITP, with excessive platelet destruction and abnormal megakaryocyte apoptosis. ${ }^{15,16}$ In bacterial infection, apoptosis may act as a trigger switch in host cells for the inflammatory response. However, the mechanisms underlying apoptosis of human megakaryocyte Dami cells induced by HP infection remain unclear.

In this study, the ITP model mice were infected with HP to explore the relationship of HP infection with peripheral platelet formation, and the maturation and differentiation of megakaryocytes in the bone marrow. Furthermore, human megakaryocyte Dami cells were treated with HP in vitro to study the relationship between HP infection and apoptosis in these cells. Possible mechanisms were explored by introducing PDTC, a specific inhibitor of NF- $\mathrm{BB}$, and monoclonal anti-IL-17 antibodies, in order to provide a reference for clinical strategies for the prevention and treatment of HP infection in the context of ITP.

\section{Materials and Methods}

\section{Animals and Groups}

Eighteen female Balb/c mice aged 6-8 weeks old and weighing 18-20 g were purchased from the Experimental Animal Center of the Southern Medical University. They were randomly assigned to one of 3 groups with 6 mice in each: A group of normal controls, an ITP model group, and an HPinfected ITP model group. The study was approved by the Ethics Committee of the Animal Medicine Center of the Southern Medical University, and in compliance with the National Institutes of Health (NIH) Guide for the Care and Use of Laboratory Animals and Animal Welfare Act.

\section{Establishment of the ITP Mouse Model and HP Infection}

The HP\&ITP group was orally inoculated with $5.0 \times 10^{8}$ colony-forming units of bacteria in 500ul PBS four times at day $0,3,6,9$. The normal control group and the ITP model group of mice were inoculated with 500ul PBS instead of the bacterial solution. Four weeks after HP inoculation, $2 \mu \mathrm{g}$ of rat anti-mouse CD41 monoclonal antibody (BD Bioscience) diluted with 200 ul PBS was injected intraperitoneally into balb/c mice of the HP\&ITP group and the ITP group for 5 consecutive days. ${ }^{24}$ In addition, the normal control group was injected with 200 ul PBS daily for 5 days. Blood samples were taken from the caudal vein of the mice before each antibody injection. Once the platelet count is below half the normal (premodel) level, the ITP model is confirmed as successfully established. The serum samples were collected for anti-HP antibody testing. The stomach tissue samples were prepared for histopathological examination and PCR.

\section{HP Strain Culture}

The frozen HP strain (Sydney strain, SSI) was removed from a liquid nitrogen tank and quickly placed in a water 
bath at $37{ }^{\circ} \mathrm{C}$ for gentle melting. After centrifugation for 3 $\min$ at $3000 \mathrm{r} \cdot \mathrm{min}^{-1}, 50 \mu \mathrm{L}$ were aspirated, and the supernatant was discarded. The sample was then mixed by pipetting and inoculated into brain agar infusion blood agar at $37{ }^{\circ} \mathrm{C}$ for micro-aerobic culture under the following conditions: $10 \%$ carbon dioxide, $5 \%$ oxygen, and $85 \%$ nitrogen. The bacteria were relocated into $20 \mathrm{~mL}$ of sterile HP liquid medium and placed in a shaker on a three-gas incubator under micro-aerobic conditions at $37^{\circ} \mathrm{C}$, under $100 \mathrm{r} \cdot \mathrm{min}^{-1}$ for 24 to $30 \mathrm{~h}$. UV spectrophotometer to detect bacterial concentration $\left(1.0 \mathrm{~A}_{600}=1 \times 10^{8} \mathrm{CFU} / \mathrm{mL}\right)$.

\section{Human Megakaryocyte Dami Cell Culture}

The human megakaryocytic cell line (Dami cell) was purchased from the American Type Culture Collection (ATCC, Manassas, VA, USA) and authenticated by its manufacturer. Dami cells were suspended in RPMI 1640 medium (Gibco, Grand Island, NY, USA) containing 10\% heat-inactivated fetal bovine serum (Gibco, Grand Island, NY, USA) and 100 $\mathrm{U} \cdot \mathrm{mL}^{-1}$ of cyan/streptomycin double antibiotic, and cultured at $37{ }^{\circ} \mathrm{C}$ under $5 \% \mathrm{CO}_{2}$ saturated humidity. When the cell density reaches $90 \%$, it is passaged.

\section{Treatment of Dami Cells with HP}

Dami cells in the logarithmic growth phase were collected by centrifugation. The cell culture medium was resuspended and adjusted to a concentration of $2 \times 10^{5}$ cells/ $\mathrm{mL}$ under the microscope. Then, it was inoculated into a 6 well plate (NEST Biotechnology, Wuxi, China) at $2 \mathrm{~mL}$ per well and placed in an incubator at $37{ }^{\circ} \mathrm{C}$ and $5 \%$ carbon dioxide. When the Dami cells grew to $80 \%$, replacing the fresh medium, and adding the HP bacteria suspension according to the number of bacteria: cell number $=100: 1$, and co-culturing for $0 \mathrm{~h}, 3 \mathrm{~h}, 6 \mathrm{~h}, 9 \mathrm{~h}$ at $37^{\circ} \mathrm{C}$, $5 \%$ carbon dioxide.

\section{Flow Cytometry for the Evaluation of Apoptosis of Dami Cells}

Several groups of Dami cells were collected, including Dami cells treated with the HP time gradient, control Dami cells, Dami cells treated with HP for $6 \mathrm{~h}$, Dami cells treated with $18 \mu \mathrm{mol} \mathrm{L}^{-1}$ PDTC and HP for $6 \mathrm{~h}$, and Dami cells treated with HP of $50 \mathrm{ug} \mathrm{mL}^{-1}$ anti-IL-17 neutralizing antibody and HP for $6 \mathrm{~h}$. The cell concentration was adjusted to $2 \times 10^{6}$ cells $/ \mathrm{mL}$ under microscopy. Next, $1 \mathrm{~mL}$ of cell suspension was centrifuged, collected, and precipitated, and then washed with PBS twice. $500 \mu \mathrm{L}$ of binding buffer was then added to resuspend cells. After adding $10 \mu \mathrm{L}$ of phospholipid-binding protein (Annexin V-FITC) and $5 \mu \mathrm{L}$ of Propidium Iodide (PI), cell apoptosis was evaluated with flow cytometry after incubation for 15 min at room temperature (BD Bioscience, USA).

\section{Transmission Electron Microscope (TEM)}

At $4{ }^{\circ} \mathrm{C}$, the cells were fixed with an electron microscope fixation solution for 2-4 h, and then rinsed 3 times with $0.1 \mathrm{~mL} / \mathrm{L}$ phosphate buffer PB (pH7.4), and fixed with $10 \mathrm{mg} / \mathrm{mL}$ hungry acid for $2 \mathrm{~h}$, and then rinsed 3 times again. The cells were dehydrated with $500 \mathrm{~mL} / \mathrm{L}$ ethanol, $700 \mathrm{~mL} / \mathrm{L}$ ethanol, $800 \mathrm{~mL} / \mathrm{L}$ ethanol, $900 \mathrm{~mL} / \mathrm{L}$ ethanol, $950 \mathrm{~mL} / \mathrm{L}$ ethanol, pure ethanol-pure acetone and pure acetone for $15 \mathrm{~min}$ each time. Acetone: 812 entrapment agent $=1: 1$ for $2-4 \mathrm{~h}$, acetone: 812 entrapment agent $=$ 2:1 overnight, pure 812 entrapment agent for $5-8 \mathrm{~h}$, pure 812 entrapment agent poured into the entrapment plate, sample inserted into the entrapment plate, $37{ }^{\circ} \mathrm{C}$ oven overnight, then $60{ }^{\circ} \mathrm{C}$ oven polymerization $48 \mathrm{~h}$. Ultrathin slicing machine slice $60 \sim 80 \mathrm{~nm}$ ultra-thin slice. And they were stained with uranium acetate saturated ethanol solution and lead citrate for $15 \mathrm{~min}$, respectively. The slices were dried overnight at room temperature. The morphological and quantitative changes of intracellular mitochondria and autophagy in the groups were observed under TEM. When apoptosis occurs, there are morphological changes in mitochondria. Autophagy, as a precursor of apoptotic bodies, can indirectly reflect the apoptosis of cells.

\section{Analysis of Apoptosis}

TUNEL staining was performed using the ApopTag Kit (Chemicon International) according to the manufacturer's instructions.

\section{Evaluation of mRNA Expression with Real-Time PCR}

After centrifugation, precipitates from each of the previously mentioned cell groups were collected, and total RNA was extracted with Trizol (Vazyme, Nanjing, China). Then, $1 \mu \mathrm{g}$ of RNA was converted into cDNA with a reverse transcription kit (Vazyme, Nanjing, China). This cDNA was used for real-time quantitative PCR (qPCR) evaluation using an iCycler thermocycler platform. The dissolution temperature was set to $64{ }^{\circ} \mathrm{C}$. The 
relative expression of the target gene was calculated using the $2^{-\Delta \Delta \mathrm{Ct}}$ method after the target gene was normalized to the expression level of the housekeeper gene (GAPDH). Gene primers are shown in Supplemental Table 1.

\section{Western Blotting}

After centrifugation, cell pellets from each of the previously mentioned cell groups were collected. After adding the cell lysate RIPA (Fudebio, Hangzhou, China), cells were placed on ice for $30 \mathrm{~min}$ and then centrifuged at $12,000 \mathrm{r} \cdot \mathrm{min}^{-1}$ for 4 min at $4{ }^{\circ} \mathrm{C}$. Next, the supernatant was collected, and protein in the supernatant was assessed with the BCA method (Fudebio, Hangzhou, China). $50 \mu \mathrm{g}$ of this protein was added to $5 \times$ loading buffer (Fudebio, Hangzhou, China) at a volume ratio of $4: 1$, and boiled at $100{ }^{\circ} \mathrm{C}$ for $5 \mathrm{~min}$ to prepare a protein sample. After loading, the protein was subjected to vertical electrophoresis at $80 \mathrm{~V}$ for $30 \mathrm{~min}$, which was then continued with $120 \mathrm{~V}$ until the bromophenol blue ran out of the glass plate. Next, the protein gel was removed, and the membrane was incubated at $100 \mathrm{~V}$ in an ice bath, while $5 \%$ of skim milk powder was incubated for $6 \mathrm{~h}$ at room temperature. Then, the corresponding primary antibodies (1:1000) for Bax, Bcl-2, P65, p-P65, p-IKB $\alpha$, IL-17, and GAPDH (Affinity biosciences OH, USA) were added to shake at $4{ }^{\circ} \mathrm{C}$ overnight. The sample was then washed with TBST washing solution, and horseradish peroxide was added. Next, the enzyme-labeled secondary antibody (1:5000) was incubated at $37{ }^{\circ} \mathrm{C}$ for $1 \mathrm{~h}$. After washing with TBST, it developed with an ECL illuminant (Fudebio, Hangzhou, China), and images were acquired using an automated gel imaging system.

\section{Enzyme-Linked Immunosorbent Assay (ELISA) for Anti-HP Antibody Detection}

The HP antigen $(1.0 \mu \mathrm{g})$ was diluted with coated buffer, adding $0.1 \mathrm{~mL}$ diluent per hole, followed by incubation at $4{ }^{\circ} \mathrm{C}$ overnight. The wells were washed 3 times the next day. $0.1 \mathrm{~mL}$ of serum samples diluted 1:200 was added to the above-coated wells, incubated at $37{ }^{\circ} \mathrm{C}$ for $1 \mathrm{~h}$, and washed. Adding enzyme-labeled second antibody $0.1 \mathrm{~mL}$, incubated at $37{ }^{\circ} \mathrm{C}$ for $60 \mathrm{~min}$, and washed, adding $0.1 \mathrm{~mL}$ tetramethylbenzidine (TMB) substrate solution to each reaction pore, followed by incubation in the dark at $37{ }^{\circ} \mathrm{C}$ for $10 \mathrm{~min}$. The reaction was halted by adding $0.05 \mathrm{~mL}$ of $2 \mathrm{~mol} / \mathrm{L}$ sulfuric acid. The $\mathrm{OD}$ value $\left(\mathrm{OD}_{490}\right)$ of each hole was measured on ELISA detector
(Molecular Devices Japan, Tokyo, Japan), it was positive if it was 2.0 times higher than that of negative control OD.

\section{Statistical Methods}

The data were analyzed with SPSS 20.0 statistical software. Continuous data conforming to normal distribution was represented as mean $\pm \mathrm{SEM}$. Comparisons between two groups were performed with the LSD $t$-test, while comparisons among multiple groups were performed with one-way analysis of variance (ANOVA). Differences were considered statistically significant when $\mathrm{p}<0.05$.

\section{Results}

\section{Effects of Treatment with HP on the Classification of Platelets and Bone Marrow Megakaryocytes in ITP Model Mice}

The platelet count in the model group was significantly lower than in the normal control group. Similarly, the platelet count was significantly lower in mice treated with HP than in the model group (Figure 1A). The infection of $\mathrm{H}$. pylori was determined by anti- HP antibody and histopathological examination of gastric mucosa. The increase in the proportion of anti-HP antibody and chronic inflammation of gastric mucosal lamina propria can indirectly explain HP infection. In addition, if we carefully observe the pathological HE staining of gastric mucosa, we can see the colonization of HP mucosa directly.We can clearly see from the HE picture that HP group can obviously induce chronic inflammation in the lamina propria of gastric mucosa, which is characterized by infiltration of inflammatory cells and atrophy of mucosal epithelium (Figure 1B and C). After modeling, the number of bone marrow megakaryoblast and granular megakaryocytes were significantly increased in the model group, while the number of plate megakaryocytes was decreased. There was a significant difference between these two groups. After treatment with HP, the number of bone marrow megakaryoblast and granular megakaryocytes were significantly increased, while the number of plate megakaryocytes was decreased, in comparison with the model group (Figure 1D). Then, we further analyzed the spleen index and thymic index of each group and found that the spleen index was significantly increased, while the thymus index was decreased after treated with HP in comparison with the model group (Figure 1E). The spleen index and thymus index could accurately reflect the immune ability of the body. By measuring the organ index of each group of 

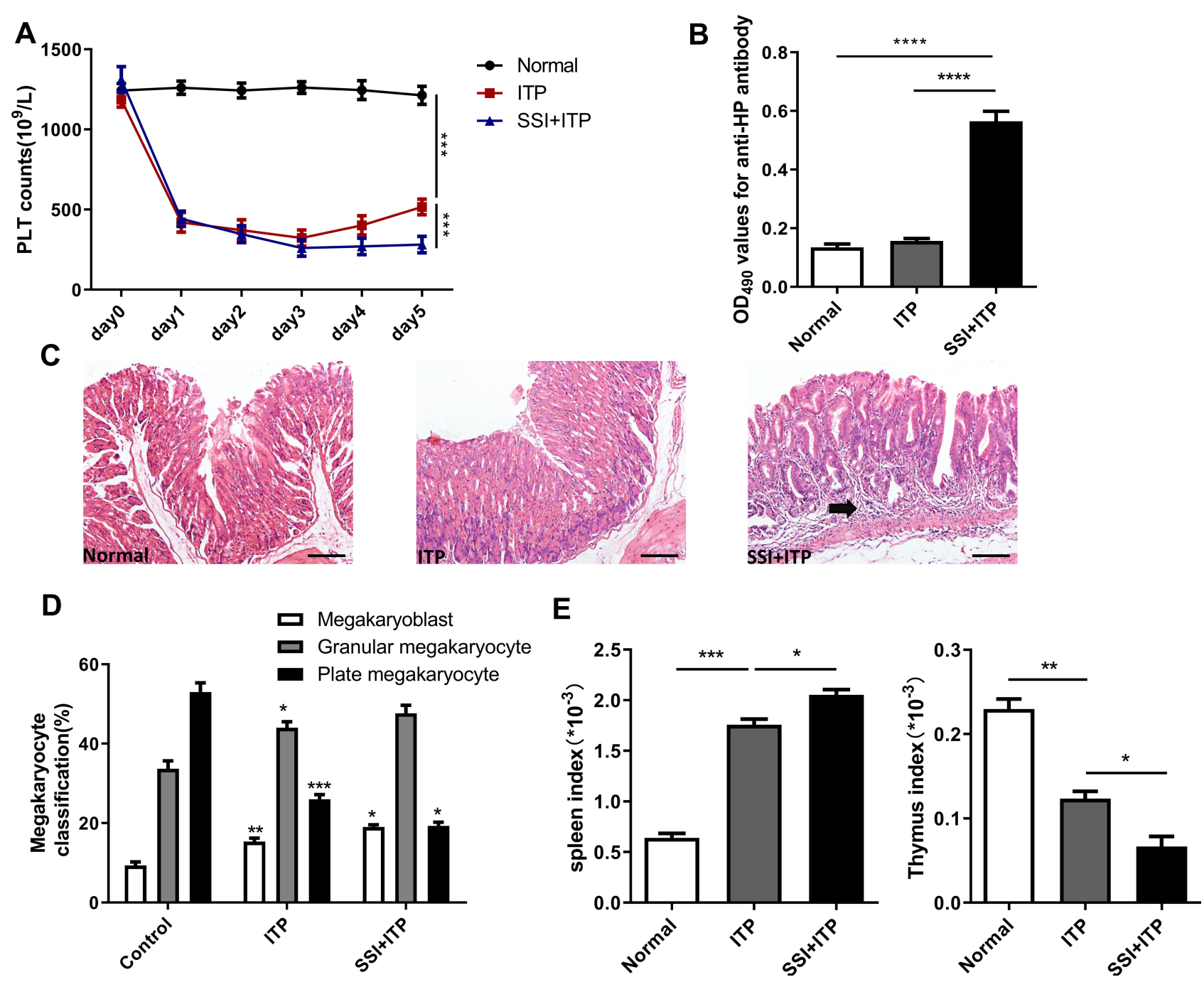

Figure I HP infection significantly reduced the number of platelets in murine models. (A) Platelet counts were enumerated before each anti-CD4I antibody injection. (B) Enzyme-linked immunosorbent assay (ELISA) for anti-HP antibody detection. (C) Representative histopathology images from stomach tissue on day 5. (D) Bone marrow cell smears were taken out to observe the morphology and primary classification of megakaryocytes (megakaryoblast, granular megakaryocytes, and plate megakaryocytes). (E) Effects of SSI on spleen Index and thymic Index in ITP Model mice. (Spleen index = spleen weight/mouse body weight $(\mathrm{g}) \times 100 \%)$; Thymus index $=$ thymus weight/mouse weight $(\mathrm{g}) \times 100 \%$. All data represent mean $\pm \mathrm{SEM} ; \mathrm{n}=6 ;{ }^{*} \mathrm{p}<0.05,{ }^{*} \mathrm{p}<0.0 \mathrm{I},{ }^{*} *{ }^{*} \mathrm{p}<0.00 \mathrm{I},{ }^{*} * * *^{*}<0.000 \mathrm{I}$ versus vehicle. Analysis of Variance (ANOVA) and Student's $t$-test (two-tailed).

mice, the results showed that the immune function in the ITP process is abnormal; HP infection could aggravate this abnormal change.

\section{Effect of Treatment with HP on Apoptosis of Dami Cells}

Dami cells treated with HP were collected after $6 \mathrm{~h}$ of exposure. The apoptosis rate of Dami cells was assessed with flow cytometry at four different time points, with significant differences among these groups. The apoptosis rate of Dami cells increased gradually with HP exposure. The most noticeable change was observed at $6 \mathrm{~h}$, and there were significant differences between the apoptosis rates at
$0 \mathrm{~h}$ in comparison with $3 \mathrm{~h}, 6 \mathrm{~h}$, and $9 \mathrm{~h}$ (Figure 2A). Under the transmission electron microscope, the chromatin of apoptotic cells was concentrated and usually distributed along the nuclear membrane. The morphology of the whole cells changed, such as the disappearance of microchorionic protrusions on the surface of cells, the disappearance of contact between cells, the concentration and aggregation of cytoplasm, and the formation of apoptotic bodies with membrane structure. These changes were most evident at $6 \mathrm{~h}$ (Figure 2B). And tunel staining results were consistent with previous ones. Moreover, the expression of apoptotic genes was assessed with fluorescence quantitative PCR. Bax expression increased gradually with the 


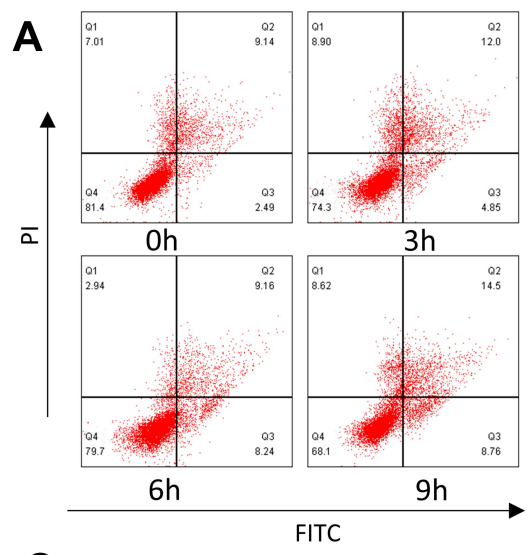

C
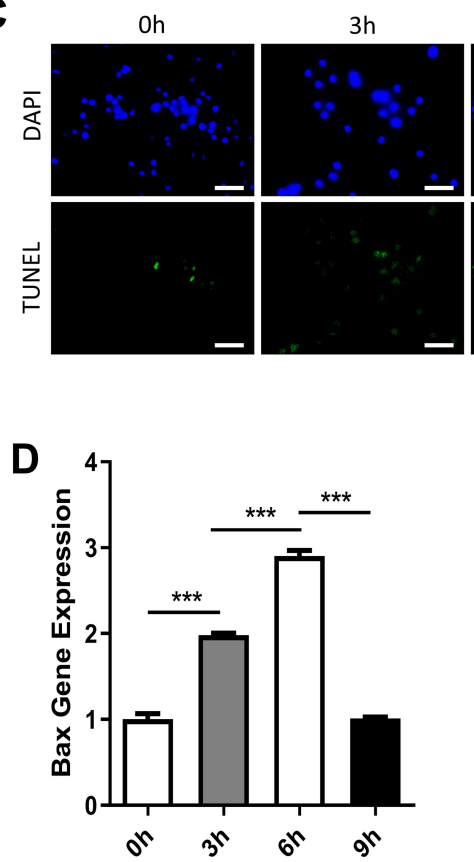

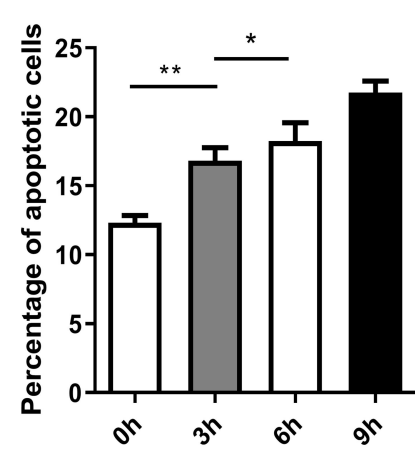

$6 h$
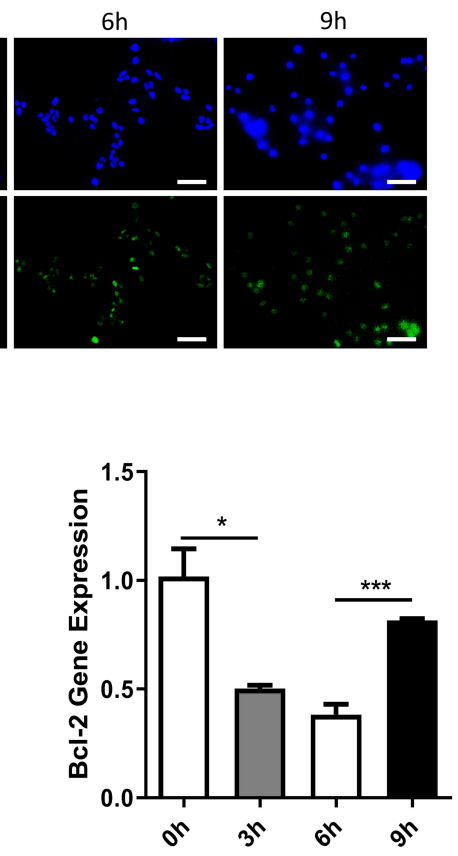

B

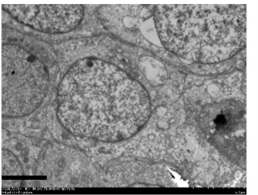

$\mathrm{Oh}$

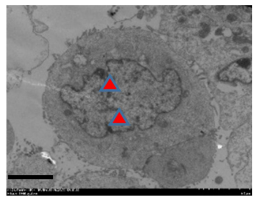

$6 \mathrm{~h}$

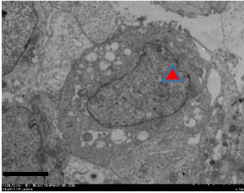

$3 \mathrm{~h}$

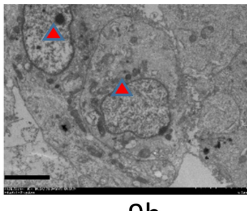

E

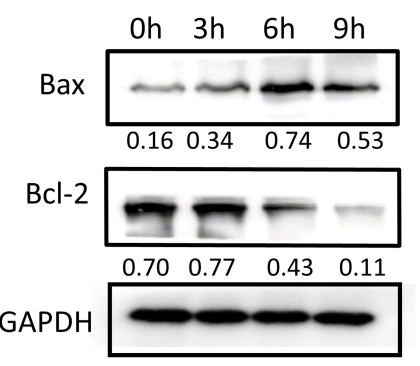

Figure 2 Effect of treatment with HP on apoptosis of Dami cells. (A) Flow cytometric analysis of apoptotic Dami cells after treated with HP at Oh, 3h, 6h, 9h; Statistical analysis was obtained by calculating the percentage of apoptotic population from three independent experiments on Dami cells, respectively; (B) TEM analysis of apoptotic Dami cells after treated with HP at 0h, 3h, 6h, 9h; Scale bars: I um; (C) TUNEL staining of apoptotic Dami cells after treated with HP at 0h, 3h, 6h, 9h; Scale bars: I00 um; (D) relative mRNA expression levels of apoptosis-related genes (Bax and Bcl-2) were measured in Dami cells by qPCR analysis; (E) protein levels of Bax and Bcl-2 were detected in Dami cells by Western blot analysis; All data are expressed as mean \pm SEM $(n \geq 3)$. ${ }^{*} p<0.05,{ }^{* *} p<0.01$, ${ }^{* * *} p<0.00$ I versus vehicle. Analysis of Variance (ANOVA) and Student's t-test (two-tailed).

prolongation of HP exposure. The most noticeable change was ascertained at $6 \mathrm{~h}$, and there were significant differences in the expression of Bax gene between the group at $0 \mathrm{~h}$ in comparison with $3 \mathrm{~h}, 6 \mathrm{~h}$, and $9 \mathrm{~h}$.

In contrast, Bcl-2 expression decreased progressively with HP exposure, with the most noticeable change at 6 $\mathrm{h}$. There were significant differences in Bcl-2 expression at $3 \mathrm{~h}, 6 \mathrm{~h}$, and $9 \mathrm{~h}$ (Figure 2D). After total protein extraction, the expression of apoptosis-related proteins was assessed with Western blotting. Similarly, Bax expression increased progressively with HP treatment, with the most notorious change at $6 \mathrm{~h}$. There were significant differences in Bax expression at $3 \mathrm{~h}, 6 \mathrm{~h}$, and $9 \mathrm{~h}$. On the other hand, Bcl-2 expression decreased gradually with HP treatment, with the most notable change at $6 \mathrm{~h}$. There were also significant differences in Bcl-2 expression at $3 \mathrm{~h}, 6 \mathrm{~h}$, and $9 \mathrm{~h}$ (Figure 2E).

\section{Treatment with HP Promotes Apoptosis of Dami Cells Through the NF- $\mathrm{KB} / \mathrm{IL}-17$ Pathway}

After treatment with HP for $0 \mathrm{~h}, 3 \mathrm{~h}, 6 \mathrm{~h}$, and $9 \mathrm{~h}, \mathrm{mRNA}$ and total protein were extracted from Dami cells. NF- $\mathrm{KB}$ p65 mRNA and IL-17mRNA expression increased gradually with the prolongation of HP exposure. The most noticeable 
change was ascertained at $6 \mathrm{~h}$, and there were significant differences in the expression of NF- $\kappa$ B p65 or IL-17 gene between the group at $0 \mathrm{~h}$ in comparison with $3 \mathrm{~h}, 6 \mathrm{~h}$, and $9 \mathrm{~h}$ (Figure 3A). We detected the changes of IL-17 cytokines in the cell culture supernatant by ELISA. The results also showed that HP could significantly stimulate the secretion of IL-17 by Dami cells, which was most evident at $6 \mathrm{~h}$ after stimulation (Figure 3B). Likewise, the expression of NF- $\mathrm{BB}$ p65 or IL-17 protein was detected by Western blotting at different time points. There were no significant differences in the expression of total p65 protein between $0 \mathrm{~h}, 3 \mathrm{~h}, 6 \mathrm{~h}$, and $9 \mathrm{~h}$. However, the expression of p-p65 protein and IL-17 protein changed significantly at $0 \mathrm{~h}, 3 \mathrm{~h}, 6 \mathrm{~h}$, and $9 \mathrm{~h}$, and the overall difference was statistically significant. The most obvious change was found at $6 \mathrm{~h}$ (Figure 3C).

In order to ascertain whether exposure to HP promotes apoptosis of Dami cells through the NF- $\kappa \mathrm{B} / \mathrm{IL}-17$ signaling pathway, Dami cells were co-treated for $6 \mathrm{~h}$ with HP and either PDTC, an NF-кB pathway inhibitor. Significant differences were observed in the apoptosis rate of Dami cells in the control group, HP treatment group, HP, and PDTC combined treatment group. In comparison with the control of Dami cells, apoptosis was significantly increased after HP treatment for $6 \mathrm{~h}$. After combined treatment with HP and PDTC, apoptosis was significantly higher than in the control group but lower than in the
A
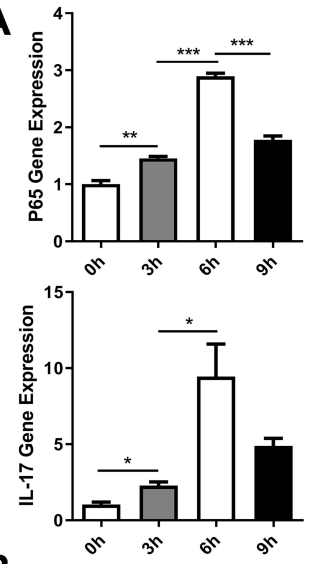

B
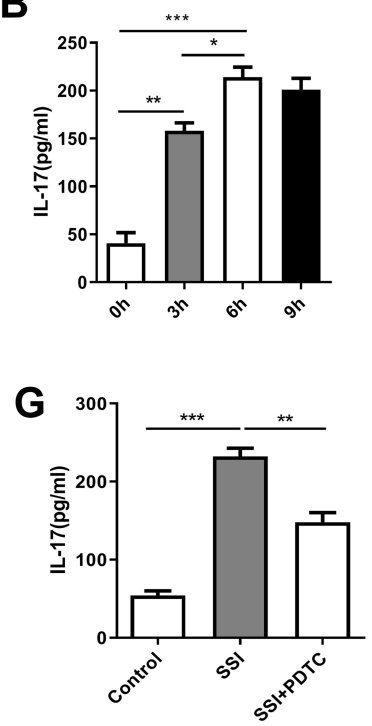

C
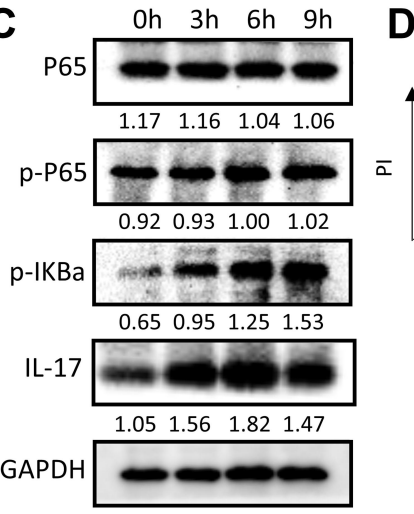

$\mathbf{E}$
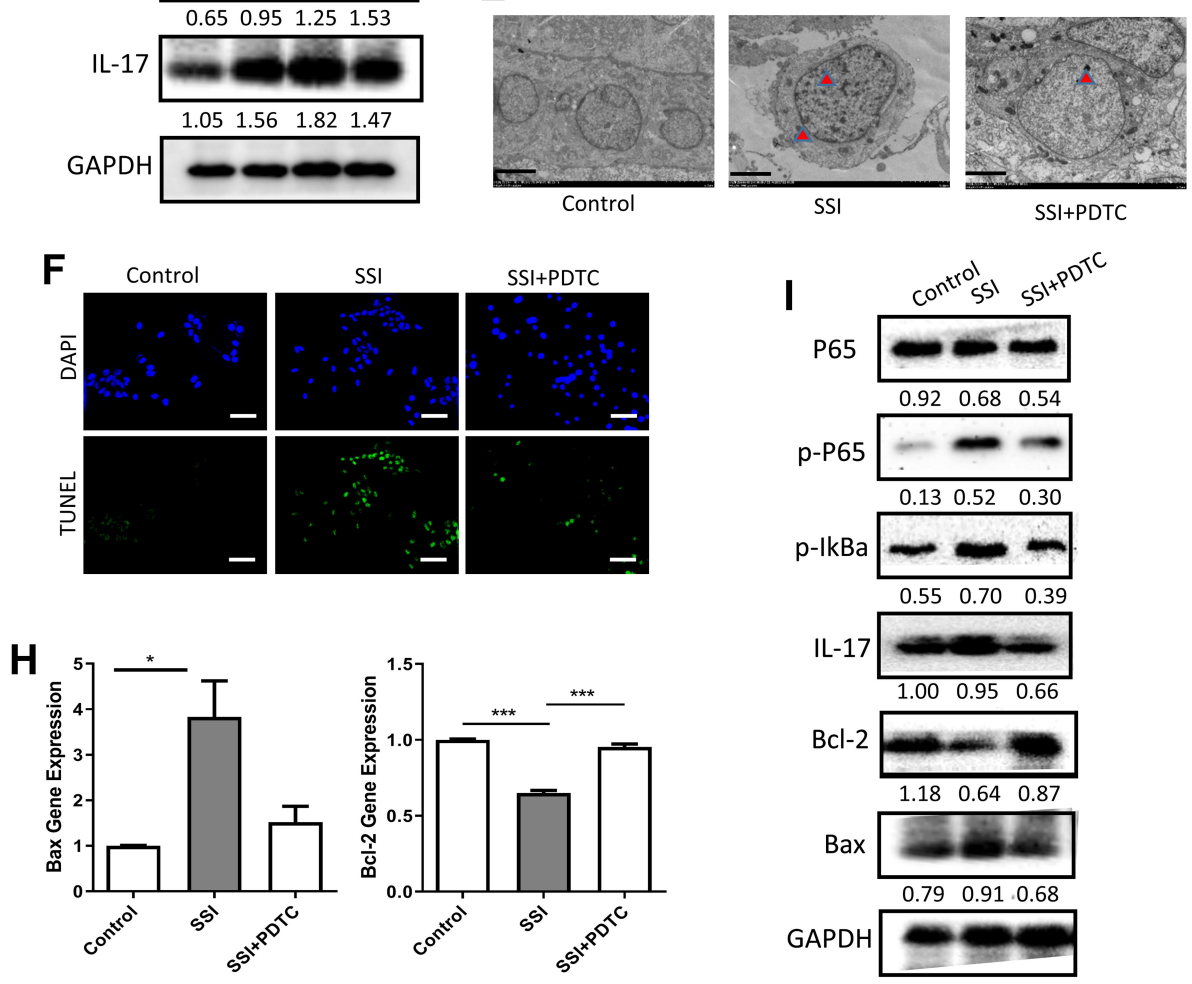

Figure 3 Treatment with HP promotes apoptosis of Dami cells through the NF- $\kappa B / I L-17$ pathway. (A) Relative mRNA expression levels of apoptosis-related genes (P65 and IL-17) were measured in Dami cells by QPCR analysis; (B) protein levels of IL-I7 were detected in culture supernatation of Dami cells by ELISA analysis; (C) protein levels of total P65, p-P65, p-IKB $\alpha$, IL-I7 and GAPDH were detected in Dami cells by Western blot analysis; (D) flow cytometric analysis of apoptotic Dami cells. The difference of apoptosis rates among four groups was analyzed; (E) TEM analysis of apoptotic Dami cells; Scale bars: I um; (F) TUNEL staining of apoptotic Dami cells; Scale bars: I00 um; (G) protein levels of IL- 17 were detected in culture supernatation of Dami cells by ELISA analysis; $(\mathbf{H})$ relative mRNA expression levels of apoptosis-related genes (Bax and Bcl-2) were measured in Dami cells by qPCR analysis; (I) protein levels of total P65, p-P65, p-IKB $\alpha$, IL-I7 and GAPDH were detected in Dami cells by Western blot analysis; All data are expressed as mean \pm SEM $(n \geq 3)$. ${ }^{*} p<0.05$, ${ }^{* *} p<0.01$, ${ }^{* * *} p<0.001$ versus vehicle. Analysis of Variance (ANOVA) and Student's $t$-test (two-tailed). 
group treated with HP alone (Figure 3D-F). We detected the changes of IL-17 cytokines in the cell culture supernatant of each group and found the same trend (Figure 3G). At the gene and protein levels, Hp stimulation increased the expression of Bax but inhibited the expression of Bcl-2, PDTC treatment could reverse this change significantly (Figure 3H). Similarly, Hp stimulation promoted phosphorylation of IKB $\alpha$ and NF- $\kappa B$ P65, while PDTC treatment inhibited these phosphorylation processes (Figure 3I).

\section{Discussion}

The establishment of the mouse ITP animal model plays an essential role in the study of ITP and has made significant contributions in the search for new treatments for this disease. ${ }^{17}$ Although some studies have implemented irrigation with chemical reagents such as cyclophosphamide to establish the ITP model, the concomitant impact of these drugs in the hematopoietic function of the bone marrow affects the experimental results. It cannot adequately replicate the pathogenesis of ITP. Irradiation at 60Go was another method for establishing this model, which offers a specific capacity for recovery; however, it appeared to impact the results of the studies still significantly and was later abandoned. As the understanding of ITP deepened in the late 20th century, the preparation of the model gradually turned to immune methods. In order to investigate the mechanisms underlying the effects of HP infection in ITP, a stable ITP mouse model was established (Figure 1A).

Most patients with ITP have abnormal megakaryocyte maturation or function, especially dysplasia, which results in a severe reduction of the platelet count. Our results showed the number of immature cells in the model group was significantly higher than in the control group, indicating mice in the model group had alterations in bone marrow megakaryocyte differentiation and maturation, affecting platelet production. After the administration of HP in the ITP model, the number of megakaryocytes with dysplasia further increased, while the number of plate megakaryocyte further decreased compared with the ITP group (Figure 1B). This indicates HP infection may promote heterogeneous differentiation of bone marrow megakaryocytes, inhibiting their differentiation and maturation.

Apoptosis is the active process of cell death regulated by genes through which aging and abnormal cells are cleared. ${ }^{18}$ Treatment with HP induced apoptosis in human megakaryocyte Dami cells. Annexin V-FITC/PI double staining was used to label cells treated with HP for $0 \mathrm{~h}, 3 \mathrm{~h}, 6 \mathrm{~h}$, and $9 \mathrm{~h}$. Flow cytometry was used to detect apoptotic cells, revealing the apoptosis rate increased significantly at $3 \mathrm{~h}$ after HP exposure. However, the change in the apoptosis rate was most significant at $6 \mathrm{~h}$ (Figure 2A). TEM examination showed that the number of apoptotic bodies in the apoptotic cells at this time was the largest (Figure 2B). Genes in the Bcl-2 family, such as Bcl-2 and Bax are crucial for the regulation of apoptosis. ${ }^{19}$ The Bcl-2 protein appears to inhibit the apoptosis process by blocking a new signaling link for programmed cell death, whereas the Bax protein forms dimers with Bcl-2 to inactivate it, thus regulating apoptosis. Our results showed that the expression of Bax increased significantly $3 \mathrm{~h}$ after HP exposure, while the most significant change was at $6 \mathrm{~h}$. Moreover, Bcl-2 protein expression decreased gradually with increasing HP exposure time, indicating treatment with HP promoted apoptosis in Dami cells (Figure 2D and E).

$\mathrm{NF}-\kappa \mathrm{B}$ is a multidirectional nuclear transcriptional regulator. The NF- $\kappa \mathrm{B}$ system is involved in many processes such as inflammation, immunity, and cellular apoptosis, and is composed of the NF- $\mathrm{KB}$ family and their inhibitors, the I $\kappa \mathrm{B}$ family. ${ }^{14,20}$ One of the main functions of I $\kappa$ B is to "trap" NF- $\kappa B$ in the cytoplasm. When the NF$\kappa \mathrm{B}$ dimer $\mathrm{p} 50 / \mathrm{p} 65$ and its inhibitor $\mathrm{I} \kappa \mathrm{B} \alpha$ are inactivated and stimulated by pathogen infection, IKK is activated, resulting in phosphorylation of I $\mathrm{I} B \alpha$ and degradation of the inactive polymer. The nuclear localization sequence of the NF- $\mathrm{KB}$ dimer is then exposed. Next, it is translocated to the nucleus and binds to the target protein. One of the classical pathways of NF- $\mathrm{KB}$ activation is the binding of IL-1 and TNF- $\alpha$ to their corresponding receptors on the cell surface, which leads to activation of the NF- $\mathrm{kB}$ system and polyubiquitylation of phosphorylated IкB. ${ }^{14,20}$ Finally, the NF- $\mathrm{\kappa B}$ complex dissociates and is degraded after acting on the target gene. In this study, we explored the effect of treatment with HP on the NF- $\mathrm{kB}$ signaling pathway. We found treatment with HP significantly promoted the expression of the p-p65 protein, progressively increasing with stimulation time, suggesting HP infection can affect NF- $\mathrm{KB}$ signaling (Figure $3 \mathrm{C}$ ). In order to further verify whether HP infection regulates the apoptosis of Dami cells through the NF- $\mathrm{BB}$ signaling pathway, PDTC, a specific NF- $\kappa \mathrm{B}$ inhibitor, was used to act on Dami cells together with HP. We found that the apoptosis of Dami cells was significantly increased after HP treatment compared with the control group. However, after combined treatment with HP and PDTC, the apoptosis rate was 
significantly higher than in the control group but lower than in the group treated with HP alone, indicating the enhancement of Dami cell apoptosis induced by HP was related to activation of NF- $\kappa \mathrm{B}$ pathway (Figure $3 \mathrm{D}-\mathrm{F}$ ).

IL-17A, E, and F have been recognized as critical proinflammatory factors that play an essential role in the development of inflammatory autoimmune diseases. ${ }^{21}$ However, the function of IL-17B, C, D needs further study. To date, the signal transduction pathway after IL17 binds to its receptor remains unclear. IL-17 has been found to promote the expression of downstream genes through multiple signaling pathways. NF-kB activator 1 (Act1) is a vital junction protein that connects IL-17RA with various downstream signaling molecules. ${ }^{21}$ Act1 can connect the IL-17 receptor through the SEFIR region and activate downstream TRAF6 and other signal transduction molecules. ${ }^{22}$ The interaction of IL-17 with IL-1 $\beta$ and TNF- $\alpha$ can promote the phosphorylation of p65 and I $\mathrm{B}$ and activate the NF- $\kappa$ B pathway. In turn, IL- $1 \beta$ and TNF- $\alpha$ are involved in a positive feedback loop with NF- $\kappa B$ : They are both essential inducible factors in NF- $\kappa$ B pathway, and their expression can induce $N F-\kappa B$ activation, which in turn can regulate the transcription and expression of TNF$\alpha$ and IL-1 $\beta$. Activation of NF- $\kappa B$ can increase the transcription of the TNF- $\alpha$ and IL- $1 \beta$ genes, and then reactivate $\mathrm{NF}-\kappa \mathrm{B}$, further upregulating inflammation. ${ }^{23}$ By assessing the effects of HP exposure on IL-17 signaling, we found it could significantly promote the expression of the IL-17 gene and protein, progressively increasing with HP stimulation time (Figure $3 \mathrm{~B}$ and $\mathrm{C}$ ), while PDAC treatment could inhibit this effect (Figure 3I). These results suggest HP infection can affect the expression of IL-17 signaling pathway protein.

In conclusion, HP infection may promote the development of ITP, possibly by inducing apoptosis of human

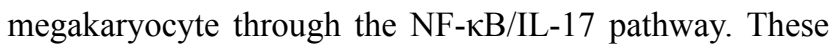
results may provide a theoretical basis for the clinical development of new drugs for the prevention and treatment of ITP.

\section{Acknowledgments}

This study was supported by the National Natural Science Foundation of China (No. 81870144, No. 81770190, No. 81600141).

\section{Author Contributions}

All authors made a significant contribution to the work reported, whether that is in the conception, study design, execution, acquisition of data, analysis and interpretation, or in all these areas; took part in drafting, revising or critically reviewing the article; gave final approval of the version to be published; have agreed on the journal to which the article has been submitted; and agree to be accountable for all aspects of the work..

\section{Disclosure}

The authors report no conflicts of interest for this work.

\section{References}

1. Audia S, Mahevas M, Samson M, et al. Pathogenesis of immune thrombocytopenia. Autoimmun Rev. 2017;16(6):620-632. doi:10.1016/j.autrev.2017.04.012

2. Cines DB, McMillan R. Management of adult idiopathic thrombocytopenic purpura. Annu Rev Med. 2005;56:425-442. doi:10.1146/ annurev.med.56.082103.104644

3. Kavitt RT, Cifu AS. Management of Helicobacter pylori infection. JAMA. 2017;317(15):1572-1573. doi:10.1001/jama.2017.1949

4. Bogdanos DP, Sakkas LI. From microbiome to infectome in autoimmunity. Curr Opin Rheumatol. 2017;29(4):369-373. doi:10.1097/BOR.0000000000000394

5. Llovet V, Rada G. Does Helicobacter pylori eradication play a role in immune thrombocytopenia? Medwave. 2016;16(Suppl 3):e6528. doi:10.5867/medwave.2016.6528

6. Shukla SK, Singh G, Ahmad S, et al. Infections, genetic and environmental factors in pathogenesis of autoimmune thyroid diseases. Microb Pathog. 2018;116:279-288. doi:10.1016/j.micpath.2018.01.004

7. Goni E, Franceschi F. Helicobacter pylori and extragastric diseases. Helicobacter. 2016;21(Suppl 1):45-48. doi:10.1111/hel.12340

8. Gasbarrini A, Franceschi F, Tartaglione R, et al. Regression of autoimmune thrombocytopenia after eradication of Helicobacter pylori. Lancet. 1998;352(9131):878. doi:10.1016/S0140-6736(05)60004-9

9. Kohda K, Kuga T, Kogawa K, et al. Effect of Helicobacter pylori eradication on platelet recovery in Japanese patients with chronic idiopathic thrombocytopenic purpura and secondary autoimmune thrombocytopenic purpura. $\mathrm{Br} J$ Haematol. 2002;118(2):584-588. doi:10.1046/j.1365-2141.2002.03612.x

10. Inaba T, Mizuno M, Take S, et al. Eradication of Helicobacter pylori increases platelet count in patients with idiopathic thrombocytopenic purpura in Japan. Eur $J$ Clin Invest. 2005;35(3):214-219. doi:10.1111/j.1365-2362.2005.01471.x

11. Arnold DM, Stasi R. Does Helicobacter pylori eradication therapy result in a platelet count improvement in adults with immune thrombocytopenic purpura regardless of $\mathrm{H}$ pylori infection? ASH evidence-based review 2008. Hematology Am Soc Hematol Educ Program. 2008;2008(1):31-32. doi:10.1182/asheducation-2008.1.31

12. Rocha AM, Souza C, Melo FF, et al. Cytokine profile of patients with chronic immune thrombocytopenia affects platelet count recovery after Helicobacter pylori eradication. Br J Haematol. 2015;168 (3):421-428. doi:10.1111/bjh.13141

13. Franceschi F, Zuccala G, Roccarina D, et al. Clinical effects of Helicobacter pylori outside the stomach. Nat Rev Gastroenterol Hepatol. 2014;11(4):234-242. doi:10.1038/nrgastro.2013.243

14. Hoesel B, Schmid JA. The complexity of NF-kappaB signaling in inflammation and cancer. Mol Cancer. 2013;12:86. doi:10.1186/ $1476-4598-12-86$

15. von Gunten S, Wehrli M, Simon HU. Cell death in immune thrombocytopenia: novel insights and perspectives. Semin Hematol. 2013;50 (Suppl 1):S109-S115. doi:10.1053/j.seminhematol.2013.03.016 
16. Perdomo J, Yan F, Chong BH. A megakaryocyte with no platelets: anti-platelet antibodies, apoptosis, and platelet production. Platelets. 2013;24(2):98-106. doi:10.3109/09537104.2012.669508

17. Neschadim A, Branch DR. Mouse models of autoimmune diseases: immune thrombocytopenia. Curr Pharm Des. 2015;21 (18):2487-2497. doi:10.2174/1381612821666150316123436

18. Chen M, Yan R, Zhou K, et al. Akt-mediated platelet apoptosis and its therapeutic implications in immune thrombocytopenia. Proc Natl Acad Sci U S A. 2018;115(45):E10682-E10691. doi:10.1073/ pnas. 1808217115

19. Knight T, Luedtke D, Edwards H, et al. A delicate balance - The BCL-2 family and its role in apoptosis, oncogenesis, and cancer therapeutics. Biochem Pharmacol. 2019;162:250-261. doi:10.1016/ j.bcp.2019.01.015

20. DiDonato JA, Mercurio F, Karin M. NF-kappaB and the link between inflammation and cancer. Immunol Rev. 2012;246(1):379-400. doi:10.1111/j.1600-065X.2012.01099.x
21. Amatya N, Garg AV, Gaffen SL. IL-17 signaling: the Yin and the Yang. Trends Immunol. 2017;38(5):310-322. doi:10.1016/j. it.2017.01.006

22. Linden A. A role for the cytoplasmic adaptor protein Act1 in mediating IL-17 signaling. Sci STKE. 2007;2007(398):re4. doi:10.1126/ stke.3982007re4

23. Hu MM, Yang Q, Zhang J, et al. TRIM38 inhibits TNFalpha- and IL-1beta-triggered NF-kappaB activation by mediating lysosome-dependent degradation of TAB2/3. Proc Natl Acad Sci U S A. 2014;111(4):1509-1514. doi:10.1073/pnas.1318227111

24. Neschadim A, Branch DR. Mouse models for immune-mediated platelet destruction or immune thrombocytopenia (ITP). Curr Protoc Immunol. 2016;113:15.30.1-15.30.13. doi:10.1002/0471142 735.im1530s113

\section{Publish your work in this journal}

OncoTargets and Therapy is an international, peer-reviewed, open access journal focusing on the pathological basis of all cancers, potential targets for therapy and treatment protocols employed to improve the management of cancer patients. The journal also focuses on the impact of management programs and new therapeutic agents and protocols on patient perspectives such as quality of life, adherence and satisfaction. The manuscript management system is completely online and includes a very quick and fair peer-review system, which is all easy to use. Visit http://www.dovepress.com/ testimonials.php to read real quotes from published authors. 